\title{
Klippel-Trenaunay syndrome and cavernous malformations
}

\author{
Christian B Ricks, Ramesh Grandhi, Andrew F Ducruet
}

Department of Neurosurgery, University of Pittsburgh Medical Center, Pittsburgh, Pennsylvania, USA

\section{Correspondence to} Dr Andrew Ducruet, ducruetaf@upmc.edu

Accepted 19 September 2014

\section{DESCRIPTION}

A 74-year-old woman with Klippel-Trenaunay syndrome (KTS) presented to the emergency room with 3 days of right arm and leg ataxia, gait instability, dysphagia and intermittent occipital headaches. Her physical examination was notable for left upper and lower extremity hemihypertrophy and multiple cutaneous port-wine stains. A head CT without contrast revealed a $1.1 \mathrm{~cm} \times 1.4$ $\mathrm{cm}$ hyperdense focus adjacent to the distal right vertebral artery with extension into the caudal medulla, concerning for a partially thrombosed right vertebral artery aneurysm (figure 1). Diagnostic cerebral angiography, however, showed no abnormality. MRI of the brain demonstrated a $7 \mathrm{~mm}$, haemorrhagic lesion within the caudal right medulla with exophytic extramedullary extension most compatible with a haemorrhagic cavernous malformation (figure 2). She was discharged home the following day with outpatient physical and vestibular therapy with the intention to manage her cavernous malformation conservatively in the absence of progressive symptomatology.

KTS describes a rare congenital syndrome consisting of a classic triad of cutaneous haemangiomas, varicose veins and bone or soft tissue hypertrophy causing limb asymmetry. Most cases of KTS arise from sporadic mutations in one or more genes involved in early embryonic angiogenesis such as AGGF1. The central nervous system is most commonly involved through hemimegaencephaly, but vascular anomalies including multiple aneurysms, arteriovenous malformations and unique

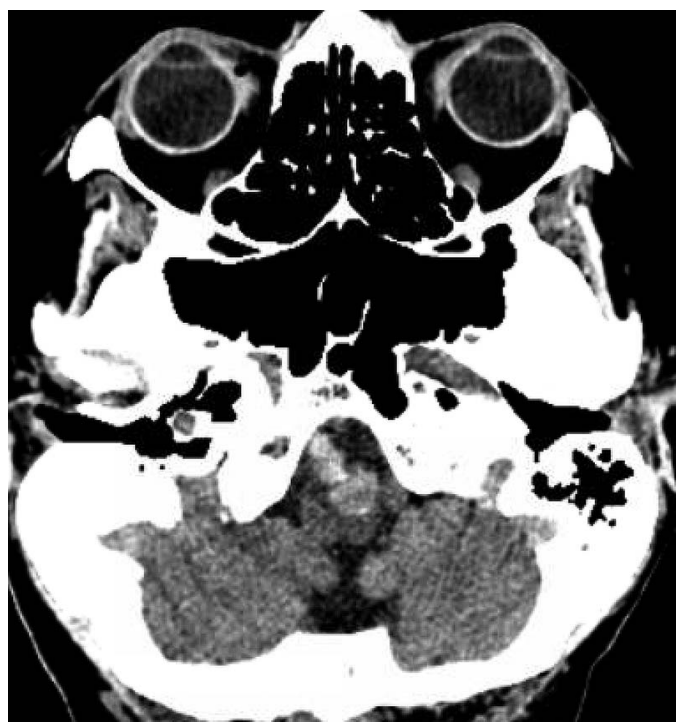

Figure $1 \mathrm{CT}$ of the head revealing a hyperdense focus with extension into medulla.

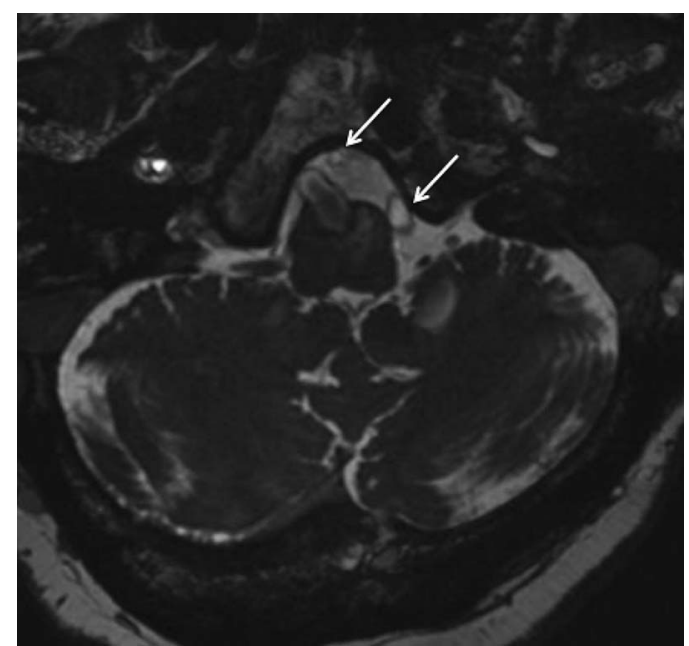

Figure 2 Axial T2 echo-gradient-weighted MRI demonstrating the $7 \mathrm{~mm}$, haemorrhagic lesion within the caudal right medulla consistent with a haemorrhagic cavernous malformation. Arrows denote right and left vertebral arteries.

capillary malformation-arteriovenous malformations have been described. To the best of our knowledge, only three patients with KTS-associated central nervous system cavernomas have been documented involving the cervical spine, ${ }^{1}$ thoracic spine and brainstem. ${ }^{23}$ All were treated conservatively.

\section{Learning points}

- Klippel-Trenaunay syndrome is a rare congenital syndrome involving the central nervous system through hemimegaencephaly, aneurysms and vascular malformations.

- Central nervous system cavernous malformations have been associated with Klippel-Trenaunay syndrome in three other reports, all managed conservatively.

Contributors $R G$ and $A D$ were involved in study concept and design, and critical revision of the manuscript for important intellectual content; CBR in acquisition of the data; and all authors were involved in analysis and interpretation of the data. CBR and RG drafted the manuscript. Administrative, technical and material supports were given by CBR and RG and $A D$ was involved in study supervision.

Competing interests None.

Patient consent Obtained.

Provenance and peer review Not commissioned; externally peer reviewed. 


\section{REFERENCES}

1 Pichierri A, Piccirilli M, Passacantilli E, et al. Klippel-Trenaunay-Weber syndrome and intramedullary cervical cavernoma: a very rare association. Case report. Surg Neurol 2006;66:203-6; discussion 6 .
2 Sudmeyer $\mathrm{M}$, Maroof $\mathrm{P}$, Saleh $\mathrm{A}$, et al. Action tremor caused by olivary cavernoma in KlippelTrenaunay syndrome mimicking asymmetric essential tremor. J Neurol 2011;258:140-2.

3 Boutarbouch M, Ben Salem D, Gire L, et al. Multiple cerebral and spinal cord cavernomas in Klippel-Trenaunay-Weber syndrome. J Clin Neurosci 2010;17:1073-5.

Copyright 2014 BMJ Publishing Group. All rights reserved. For permission to reuse any of this content visit

http://group.bmj.com/group/rights-licensing/permissions.

BMJ Case Report Fellows may re-use this article for personal use and teaching without any further permission.

Become a Fellow of BMJ Case Reports today and you can:

- Submit as many cases as you like

- Enjoy fast sympathetic peer review and rapid publication of accepted articles

- Access all the published articles

- Re-use any of the published material for personal use and teaching without further permission

For information on Institutional Fellowships contact consortiasales@bmjgroup.com

Visit casereports.bmj.com for more articles like this and to become a Fellow 